\title{
Synthesis of non-natural carbohydrates from glycerol and aldehydes in a one-pot four-enzyme cascade reaction
}

\author{
Lara Babich, $\dagger^{\dagger}$ Lieke J. C. van Hemert, $\dagger^{\dagger}$ Aleksandra Bury, ${ }^{a}$ Aloysius F. Hartog, ${ }^{a}$ Pierpaolo Falcicchio, ${ }^{c}$ \\ John van der Oost, ${ }^{c}$ Teunie van Herk, ${ }^{a}$ Ron Wever ${ }^{* a}$ and Floris P. J. T. Rutjes ${ }^{b}$
}

Received 19th April 2011, Accepted 28th June 2011

DOI: $10.1039 / \mathrm{clgc15429j}$

\begin{abstract}
A simple procedure has been developed for the synthesis of enantio- and diastereomerically pure carbohydrate analogues from glycerol and a variety of aldehydes in one pot using a four-enzyme cascade reaction. As a proof of concept of the usefulness of this enzymatic catalytic cascade the naturally occurring azasugar D-fagomine was synthesized. This work highlights the potential value of using enzymes in cascade reactions to selectively form complex products that by previous traditional organic chemistry could only be obtained via repeated isolation and purification of intermediates.
\end{abstract}

\section{Introduction}

In the search for efficient, sustainable synthetic strategies, chemists increasingly pursue approaches that are inspired by Nature. ${ }^{1}$ The ultimate goal is to mimic biosynthetic pathways and construct complex products via ingenious sequences of multiple enzymatic conversions in one pot, preferably with both high chemo- and stereoselectivity. ${ }^{2}$ This concept is demonstrated in the synthesis of complex carbohydrate building blocks, ${ }^{3}$ which may serve amongst others as intermediates for iminosugars. ${ }^{4}$ Besides impressive achievements in the chemical synthesis of carbohydrate building blocks using asymmetric catalysis ${ }^{5}$ and organocatalysis, ${ }^{6}$ use of aldolases could provide direct stereoselective access to carbohydrate structures without going through protecting group manipulations. ${ }^{7}$ In order to explore the full potential of existing aldolases in $\mathrm{C}-\mathrm{C}$ bond formation, it is crucial to have facile access to phosphorylated substrates. ${ }^{8}$ Dihydroxyacetone phosphate (DHAP) is one of the key compounds in aldol condensation using DHAP dependant aldolases and the research groups of Whitesides, Wong and Fessner have used several enzymatic procedures to arrive at the formation of DHAP starting from glycerol, ${ }^{9}$ glycerol phosphate ${ }^{10}$ or dihydroxyacetone..$^{11,12}$ These methods have the disadvantage that

a'University of Amsterdam, J. H. van't Hoff Institute for Molecular Sciences, Science Park 904, 1098 XH, Amsterdam, The Netherlands. E-mail:r.wever@uva.nl; Fax: +31 5255604; Tel: +31 5255110

${ }^{b}$ Radboud University Nijmegen, Institute for Molecules and Materials, Heyendaalseweg 135, 6525 AJ, Nijmegem, The Netherlands.

E-mail: F.Rutjes@science.ru.nl; Fax: +31 243653393; Tel: +31 243653202

${ }^{c}$ Wageningen University, Laboratory of Microbiology, 6703 CT, Wageningen, The Netherlands

$\dagger$ Both authors contributed evenly to this manuscript. kinases are needed and that regeneration of ATP is required. The group of Sheldon was among the first to explore the formation of a heptose sugar using a multi-enzyme system in which a phosphorylated intermediate was continuously generated using pyrophosphate as a phosphate donor and in which the DHAP formed was coupled enzymatically to an aldehyde. However, a $\mathrm{pH}$ switch was needed to turn off the activity of one of the enzymes and also a very high concentration of glycerol (85\%) had to be present. ${ }^{13}$

In our group, we recently reported the efficient phosphorylation of dihydroxyacetone by the acid phosphatase from Shigella flexneri ( $\mathrm{PhoN}-\mathrm{Sf})$ using pyrophosphate $\left(\mathrm{PP}_{\mathrm{i}}\right)$ as the phosphate source. In addition, it was shown that this phosphorylation process could be applied in one pot in combination with dihydroxyacetone phosphate (DHAP)-dependent rabbit muscle aldolase (RAMA) to give the desired aldol product. ${ }^{14}$ Motivated by this outcome, we now report a one-pot synthesis of chiral carbohydrate fragment $\mathbf{1}$ by the simultaneous action of four different enzymes starting from inexpensive glycerol $\mathbf{2}$ and an appropriate aldehyde (Scheme 1).<smiles>[R]C(O)[C@H](OC)C(=O)CO</smiles>

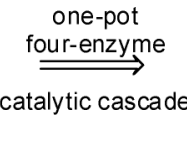<smiles>OCC(O)CO</smiles><smiles>[R]C=O</smiles>

Scheme 1 One-pot retrosynthesis of carbohydrate fragments 1.

The newly envisaged cascade was based on initial phosphorylation of glycerol into glycerol-3-phosphate, ${ }^{9,13}$ followed by L-glycerol-3-phosphate oxidase (GPO)-mediated oxidation to DHAP. Subsequent RAMA-catalyzed C-C bond formation and dephosphorylation with PhoN-Sf should then give rise to target molecules 1. Having PhoN-Sf available which operates at 
pH 6, we envisioned that we should be able to carry out the glycerol-DHAP cascade in a single pot with all enzymes acting simultaneously. ${ }^{14,15}$ Furthermore, we show that it is possible to obtain all the stereocomplementary products by using all four DHAP-dependent aldolases present in nature.

\section{Results and discussion}

Scheme 2 illustrates the sequence of events occurring in the cascade. The PhoN-Sf-mediated phosphorylation of glycerol 2 with the phosphate donor $\mathrm{PP}_{\mathrm{i}}$ produces glycerol-3-phosphate 3 in a chemoselective manner, due to the known selectivity of PhoN-Sf for primary hydroxy functions (Scheme 2). ${ }^{15}$ The L-enantiomer is then oxidized by GPO in the presence of oxygen to produce DHAP $4^{10}$ The oxidation takes place with concomitant formation of hydrogen peroxide, which is converted into water and oxygen by a third enzyme, catalase. In the next step of the cascade, DHAP reacts with the aldehyde catalyzed by RAMA to provide the phosphorylated aldol product 5. Under the reaction conditions, the aldol product is ultimately dephosphorylated by PhoN-Sf leading to enantioand diasteromerically pure diol $\mathbf{1}$. The resulting enzyme-bound phosphate may then be either transferred to water (hydrolysis) or to glycerol (transphosphorylation).$^{14}$ Hydrolysis is generally preferred over transphosphorylation so that $\mathrm{P}_{\mathrm{i}}$ is released unless a suitable substrate is present. This essentially irreversible step fortuitously shifts the thermodynamic equilibrium of the cascade to aldol product 1 once $\mathrm{PP}_{\mathrm{i}}$ becomes exhausted.

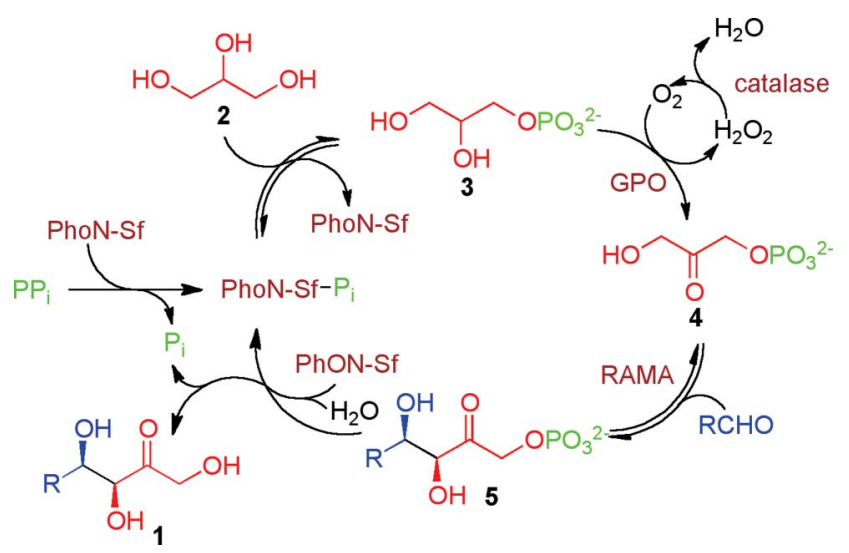

Scheme 2 Four-step one-pot catalytic cascade.

Supposedly, PhoN-Sf-induced phosphorylation of glycerol gives rise to a racemic mixture of D- and L-glycerol-3-phosphate. Since GPO would oxidize only the L-enantiomer ${ }^{10}$ the $\mathrm{D}$-isomer might accumulate. However, the acid phosphatase possesses strong transphosphorylation activity ${ }^{14}$ and most likely PhoN-Sf will transfer the phosphate group from D-glycerol-3-phosphate to glycerol resulting in racemic glycerol-3-phosphate so that accumulation of the D-isomer will not occur.

The first cascade was conducted at $0.5 \mathrm{~mL}$ scale (Table 1 , entry 1) with propanal as acceptor aldehyde. ${ }^{14} \mathrm{~A}$ solution of $500 \mathrm{mM}$ glycerol, $250 \mathrm{mM} \mathrm{PP}$ and $100 \mathrm{mM}$ propanal at $\mathrm{pH} 6$ was incubated with the four enzymes at $30^{\circ} \mathrm{C}$, resulting in $42 \%$ conversion after $24 \mathrm{~h}$. By HPLC it was possible to monitor at selected time intervals the ratio of $\mathrm{PP}_{\mathrm{i}}$ to $\mathrm{P}_{\mathrm{i}}$, the formation of
Table 1 Optimization of the four-enzyme cascade

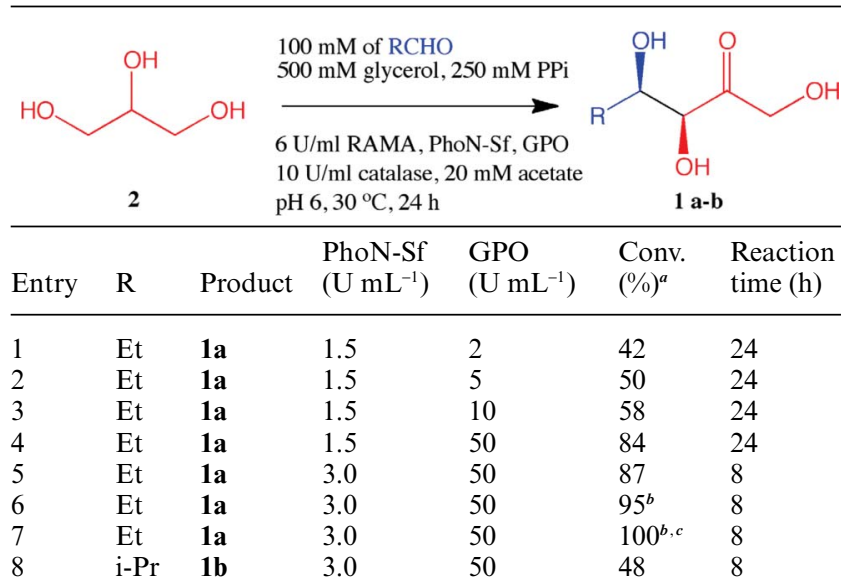

${ }^{a}$ Conversions were based on the aldehyde and determined using HPLC on aliquots of the reaction mixture. ${ }^{b}$ Reaction was performed at $20^{\circ} \mathrm{C}$. ${ }^{c}$ Reaction was performed in a closed vessel.

the phosporylated product, the dephosphorylated end product, and the amount of aldehyde converted. This allowed us to study in detail the effect of changing the amount of activity of GPO from $2 \mathrm{U} \mathrm{mL}^{-1}$ to $50 \mathrm{U} \mathrm{mL}^{-1}$ in the cascade. Optimal conversion was obtained with $50 \mathrm{U} \mathrm{mL}^{-1}$ GPO (entry 4).

Encouraged by these results the effect of changing the activity of the acid phosphatase was also investigated. When the activity of PhoN-Sf in the cascade was doubled, within $8 \mathrm{~h}$ a conversion of $87 \%$ was reached (entry 5). Changing the activity of GPO or PhoN-Sf had no effect on the diastereoselectivity, a d.r. of $14: 1$ $((3 S, 4 R)$ vs. $(3 S, 4 S))$ was observed in all cases. Lowering the temperature to $20^{\circ} \mathrm{C}$ resulted in $95 \%$ conversion and increased diastereoselectivity (entry 6). Performing the reaction in a closed vessel for $8 \mathrm{~h}$ without taking samples led to a conversion of $100 \%$ (entry 7). These effects are probably due to evaporation of the rather volatile propanal.

A branched aldehyde was also successfully used as a substrate, albeit that the yield was lower compared to propanal (Table 1 , entry 8 ), which is in line with the aldehyde specificity of RAMA. ${ }^{16}$ The cascade reaction using propanal was also performed on a $10 \mathrm{~mL}$ scale in the presence of $3 \mathrm{U} \mathrm{mL}^{-1}$ of PhoN-Sf and $50 \mathrm{U} \mathrm{mL}^{-1}$ of GPO resulting in $87 \%$ conversion and an isolated yield of $97 \mathrm{mg}(65 \%)$.

Fig. 1 shows the time course of the reaction and a comparison between the currently described cascade and the previous cascade starting from DHA instead of glycerol. ${ }^{14}$ It is obvious that the glycerol cascade is superior as compared to the DHA one. This may relate to the value of the $K_{\mathrm{m}}$ for glycerol which is $0.7 \mathrm{M}$ (not shown), whereas the $K_{\mathrm{m}}$ for DHA is $3.6 \mathrm{M}^{14}$

This may represent an important factor for the cascade reaction resulting in higher conversions compared to the DHA route. Further glycerol stabilizes most enzymes. The glycerol cascade has the additional advantage that since DHA is prone to oxidation and side reactions significantly fewer by-products are formed.

The effect of the glycerol concentration on the rate of formation was also investigated (Fig. 2). A concentration of $0.5 \mathrm{M}$ glycerol was optimal. At $1 \mathrm{M}$ glycerol both the rate 
Table 2 Four-enzyme cascade with four different aldolases and 3 different aldehydes

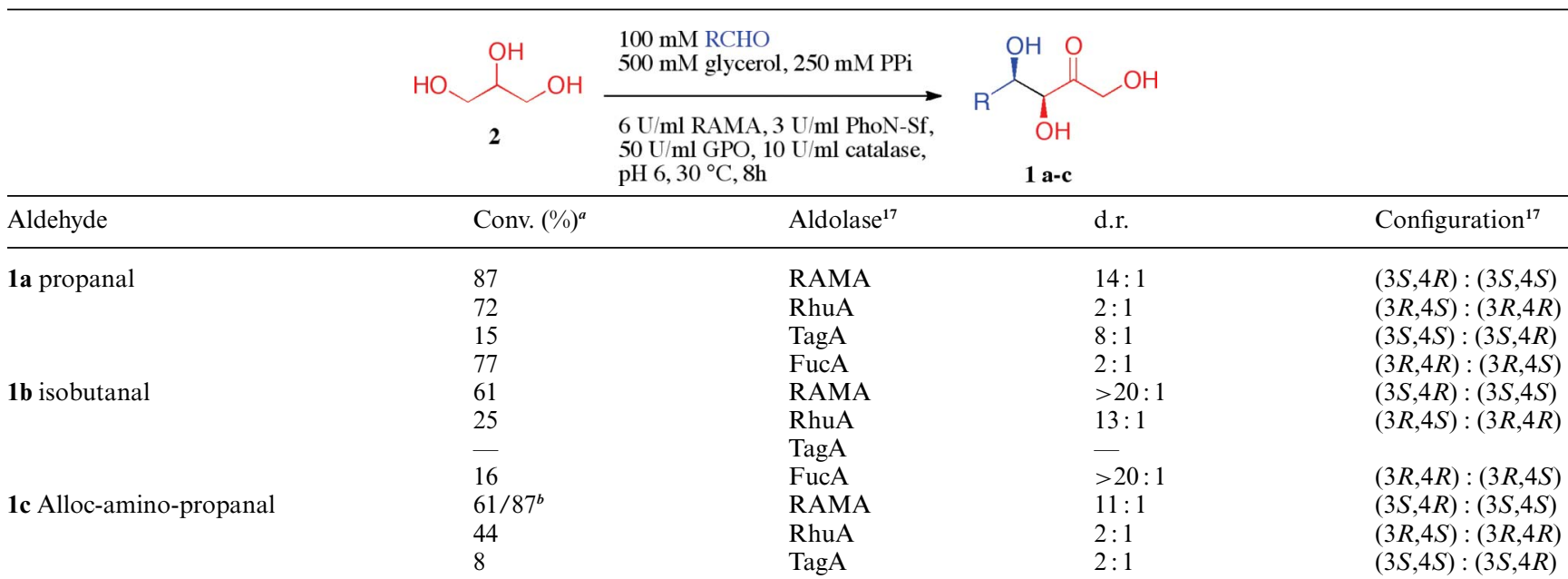

${ }^{a}$ Conversions were based on the aldehyde and determined with HPLC on aliquots of the reaction mixture. The diastereoisomeric ratio was determined based upon the peak areas in the HPLC profile and the assignments of the stereochemistry on the reported specificity of these aldolases in literature. ${ }^{17}$ ${ }^{b}$ It was possible to increase the yield by addition of an extra portion of $\mathrm{PP}_{\mathrm{i}}$.

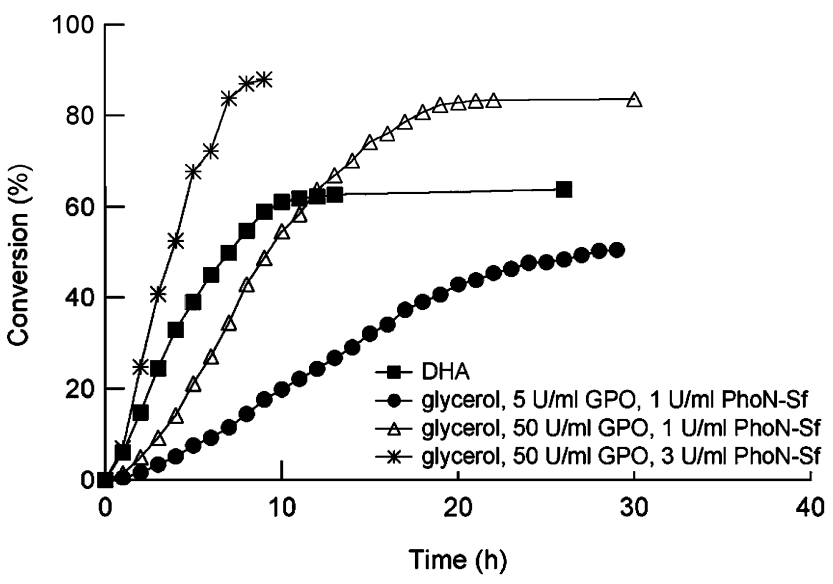

Fig. 1 Time course of the cascade reaction starting from DHA or glycerol. The reactions were carried out with $1.5 \mathrm{U} \mathrm{mL}^{-1}$ PhoN-Sf, $6 \mathrm{U}$ $\mathrm{mL}^{-1}$ RAMA, $250 \mathrm{mM} \mathrm{PP}_{\mathrm{i}}, 100 \mathrm{mM}$ propanal and $0.5 \mathrm{M}$ glycerol or 0.5 M DHA.

and the yields were lower. The lower activity at low glycerol concentrations probably relates to the $\mathrm{K}_{\mathrm{m}}$ value of PhoN-Sf for glycerol of about $0.7 \mathrm{M}$.

To probe the broader applicability of the glycerol cascade, the reaction was also carried out with three other aldolases in combination with propanal (Table 2). Rhamnulose-1-phosphate aldolase (RhuA, entry 2) and fuculose-1-phosphate aldolase (FucA, entry 4) gave similar conversions as compared to RAMA (entry 1), although the d.r. in both cases was significantly lower. In all cases the enantioselectivity with respect to the $\mathrm{C} 3$ center was complete, while $\mathrm{C} 4$ gave a 2:1 mixture in favor of the anticipated diastereoisomer. ${ }^{17}$

Tagatose-1,6-diphosphate aldolase (TagA) showed higher diastereoselectivity (entry 3), but in this case the conversion was decreased, probably due to lower activity of the aldolase (entry 3).

The efficiency of the newly developed four-enzyme cascade was evaluated in a two-step synthesis of the naturally occurring

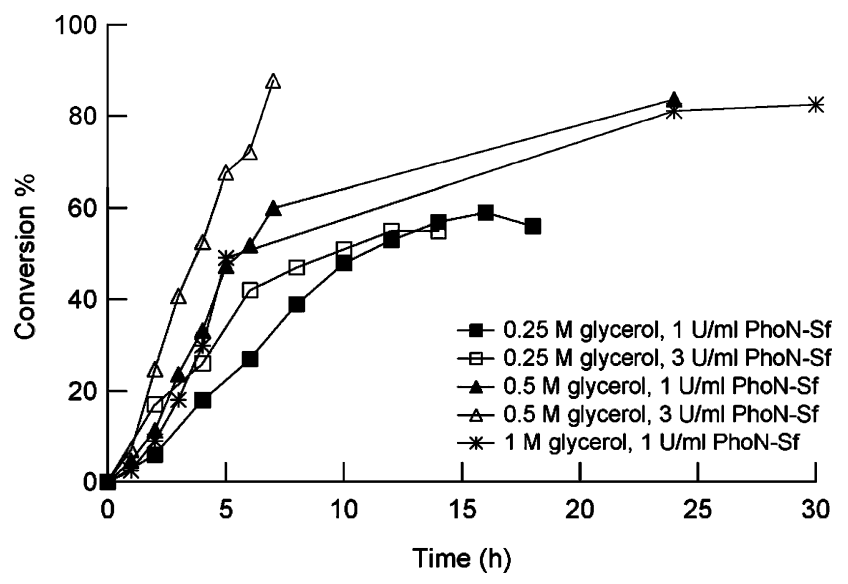

Fig. 2 Effect of glycerol concentration on the yield. $250 \mathrm{mM}$ PPi, $20 \mathrm{mM}$ acetate $\mathrm{pH} 6,100 \mathrm{mM}$ propanal, $6 \mathrm{U} \mathrm{ml}^{-1}$ RAMA, $50 \mathrm{U} \mathrm{ml}^{-1}$ GPO, $10 \mathrm{U} \mathrm{ml}^{-1}$ catalase, 1 or $3 \mathrm{U} \mathrm{ml}^{-1}$ of PhoN-Sf.

iminosugar D-fagomine (8, Scheme 3). D-Fagomine was isolated from buckwheat seeds (Fagopyrum esculentum Moench), characterized for the first time in 1974, and shown to possess relevant biological activity. ${ }^{18}$ It is a potent inhibitor of isomaltase and specific $\alpha$ - and $\beta$-galactosidases. Furthermore, D-fagomine has a potent antihyperglycemic effect in streptozocin-induced diabetic mice. Over the years, several pathways have been developed

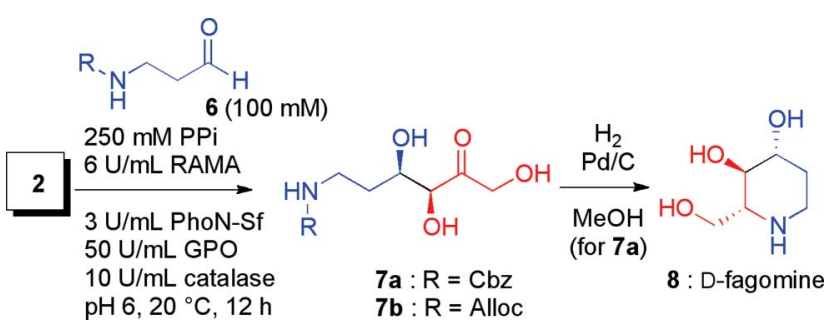

Scheme 3 Two-step synthesis of D-fagomine $(\mathbf{8})$. 
for the synthesis of D-fagomine, ${ }^{19}$ including chemoenzymatic approaches involving aldolases. ${ }^{20}$

We envisioned that the cascade with glycerol 2, RAMA and aldehyde $\mathbf{6}$ under the optimized reaction conditions would result in the formation of the intermediate product 7 (Scheme 3), which may then be converted into D-fagomine 8. The first attempt using Cbz-protected aldehyde $\mathbf{6}$ resulted in $21 \%$ isolated yield of aldol product 7a. Due to the low solubility of the aldehyde, the experiment was repeated in the presence of $10 \%$ DMSO, which resulted in a significant increase in yield to $49 \%$. Besides, an improvement of the d.r. was observed from $6: 1$ to $10: 1$. This could be due to a solvent effect on the rate of formation of one of the diastereoisomers caused by active site perturbation of the aldolase. With the more soluble Allocprotected aldehyde 6 under the optimal conditions (without cosolvent) a conversion of $75 \%$ into $7 \mathbf{b}$ was observed and a d.r. of $5: 1$. Since it was noted that the temperature of incubation had an effect on the diastereoselectivity ( $c f$. Table 1, entry 6), we also investigated the effect of temperature on the conversion and the diastereoselectivity of the resulting Alloc-modified carbohydrate 7b. There was a marked increase in the isomeric ratio from $5: 1$ to $30: 1$ when the temperature was lowered from 30 to $10{ }^{\circ} \mathrm{C}$ though the conversion dropped to approximately $50 \%$. Optimal results in terms of isolated yield were obtained at $20{ }^{\circ} \mathrm{C}$ giving product $7 \mathbf{b}$ in in $69 \%$ yield and a d.r. of $11: 1$. When instead of RAMA the RhuA aldolase derived from the thermophilic organism Thermatoga maritima was used and the temperature lowered to $10{ }^{\circ} \mathrm{C}$ the conversion dropped considerably (not shown), but unfortunately the isomeric ratio remained $2: 1$.

Subsequent Pd-mediated Alloc-deprotection of $7 \mathbf{b}(\mathrm{Pd}$ on $\mathrm{C}, \mathrm{Et}_{3} \mathrm{SiH}$ ), immediately followed by intramolecular reductive amination led to the diastereoselective formation of D-fagomine $\mathbf{8}$ in quantitative yield, thereby realizing a two-step synthesis of the natural product in $69 \%$ overall yield. ${ }^{21}$ These yields are in the same range as previously reported by the Clapés group for a two-step approach using DHA and D-fructose-6-phosphate aldolase (FSA), ${ }^{22}$ but the four-enzyme cascade has the advantage that it can also be applied to the stereocomplementary DHAPdependent aldolases.

\section{Conclusions}

A convenient procedure was developed for the production of carbohydrates in a highly enantio- and diastereoselective manner using an efficient one-pot four-enzyme catalytic cascade. This cascade starts from inexpensive reagents without need for protection-deprotection steps. The primary step is chemoenzymatic phosphorylation of glycerol and subsequent oxidation to the energy rich phosphate ester DHAP at the expense of pyrophosphate. In the same pot, the formed DHAP is coupled to a variety of aldehydes by DHAP-dependent aldolases allowing the synthesis of all four possible stereoisomers. Dephosphorylation to the final aldol product occurs once pyrophosphate is fully consumed. The value of the catalytic cascade was demonstrated in an efficient two-step synthesis of the naturally occurring azasugar D-fagomine. Thus, this approach may lead to the simple and inexpensive synthesis of a variety of non-natural heterocycles that presently can only be produced at high costs.

\section{Experimental}

\section{Chemicals and enzymes}

All chemicals were purchased from commercial suppliers and used without purification. Recombinant Shigella flexneri acid phosphatase (PhoN-Sf) was expressed in E.coli and purified as previously described. ${ }^{23}$ Catalase from bovine liver and L-glycerol-3-phosphate oxidase were purchased from SigmaAldrich and Toyobo, respectively.

Recombinant rhamnulose-1-phosphate aldolase from the thermophilic organisms T. maritima (pBAD/gIII plasmid provided by DSM) was expressed in $E$. coli strain TOP10 by inducing with $0.02 \%$ L-arabinose overnight at $28{ }^{\circ} \mathrm{C}$. The resulting culture broth was centrifuged at $6000 \mathrm{rpm}$ for $15 \mathrm{~min}$ at $4{ }^{\circ} \mathrm{C}$ and the cells were resuspended in $100 \mathrm{mM}$ Bis-Tris $\mathrm{pH}$ 6.5, $0.1 \mathrm{mM} \mathrm{ZnCl}{ }_{2}$. Cell disruption was performed by sonication followed by centrifugation at $14000 \mathrm{rpm}$ for $30 \mathrm{~min}$ at $4{ }^{\circ} \mathrm{C}$. The thermophilic enzyme RhuA was isolated from the cell free extract by heat-shock in a $70{ }^{\circ} \mathrm{C}$ water bath for $20 \mathrm{~min}$, followed by centrifugation at $14000 \mathrm{rpm}$ for $30 \mathrm{~min}$.

Tagatose-1,6-diphosphate aldolase from E. coli (pBAD plasmid supplied by DSM) was expressed in E. coli TOP10 cells and induced by $0.02 \% \mathrm{~L}$-arabinose in the presence of $0.3 \mathrm{mM}$ $\mathrm{ZnCl}_{2}$. Cells were harvested by centrifugation at $6000 \mathrm{rpm}$ for $15 \mathrm{~min}$ and resuspended in $20 \mathrm{mM}$ Tris/ $\mathrm{HCl} \mathrm{pH}$ 7.5. Cell disruption was performed by sonication. From the cellfree extract, TagA was recovered by $40 \%$ ammonium-sulfate precipitation and centrifugation at $13000 \mathrm{rpm}$ for $30 \mathrm{~min}$. The supernatant containing TagA was dialyzed overnight against $20 \mathrm{mM}$ Tris/ $\mathrm{HCl}$ pH 7.5 and loaded onto HiTrap DEAE FF 1 $\mathrm{mL}$ FPLC column for further purification. TagA was eluted at $200 \mathrm{mM} \mathrm{NaCl}$ and dialyzed against $20 \mathrm{mM}$ Tris/acetate $\mathrm{pH}$ 7.5, $0.1 \mathrm{mM} \mathrm{ZnCl}$.

Recombinant fuculose-1-phosphate (FucA) aldolase from the thermophilic bacterium T. ethanolicus (pBAD/gIII plasmid provided by DSM) was expressed in E. coli strain TOP10 by inducing with $0.02 \%$ L-arabinose overnight at $37{ }^{\circ} \mathrm{C}$. The resulting culture was centrifuged at $7000 \mathrm{rpm}$ for $15 \mathrm{~min}$ at $4{ }^{\circ} \mathrm{C}$ and the cells were resuspended in $100 \mathrm{mM}$ Tris- $\mathrm{HCl}(\mathrm{pH}$ 7.5), $150 \mathrm{mM} \mathrm{NaCl}$ and $0.1 \mathrm{mM} \mathrm{ZnCl}_{2}$. Cell disruption was performed by French Press followed by centrifugation at 17000 $\mathrm{rpm}$ for $30 \mathrm{~min}$ at $4{ }^{\circ} \mathrm{C}$. The thermophilic enzyme was isolated from the cell free extract by heat-shock in a $70{ }^{\circ} \mathrm{C}$ water bath for $20 \mathrm{~min}$, followed by centrifugation at $17000 \mathrm{rpm}$ for $30 \mathrm{~min}$ at $4{ }^{\circ} \mathrm{C}$. The supernatant containing FucA was loaded onto a Q-Sepharose FF FPLC column $(40 \mathrm{~mL})$ and eluted with a linear gradient of $\mathrm{NaCl}(0-1 \mathrm{M} \mathrm{NaCl}$ in 20 column volumes). The purified fractions were collected and desalted using $50 \mathrm{mM}$ Tris- $\mathrm{HCl} \mathrm{pH} 7.5$ and $150 \mathrm{mM} \mathrm{NaCl}$ buffer.

\section{Enzyme activity assays}

Aldolase activity was assayed by measuring the decrease of DHAP concentration in a reaction in which the aldolase performs the aldol coupling in the presence of DHAP (50 mM), rac-glyceraldehyde (100 mM), $0.1 \mathrm{mM} \mathrm{ZnCl}_{2}, 50 \mathrm{mM}$ acetate $\mathrm{pH} 6,30^{\circ} \mathrm{C}$. The decrease in DHAP concentration was assayed every $5 \mathrm{~min}$ with a coupled-enzyme system in presence of NADH-consuming glycerol-3-phosphate dehydrogenase by 
measuring NADH concentration by UV spectroscopy. Samples of the aldolase reaction mixture were diluted and incubated in $100 \mathrm{mM}$ Tris/acetate $\mathrm{pH} 7.5,0.16 \mathrm{mM} \mathrm{NADH}$, and $1 \mathrm{U} \mathrm{mL}^{-1}$ glycerophosphate dehydrogenase. The absorption was monitored at $340 \mathrm{~nm}$ at $20{ }^{\circ} \mathrm{C}$ (molar absorption coefficient $\left.6.22 \mathrm{mM}^{-1} \mathrm{~cm}^{-1}\right)$.

The $K_{\mathrm{m}}$ value of PhoN-Sf for glycerol was determined with a coupled enzyme system as described by Bergmeyer. ${ }^{24}$ L-Glycerol3-phosphate resulting from the phosphatase reaction was assayed by coupling with glycerol-3-phosphate dehydrogenase in the presence of hydrazine and $\mathrm{NAD}^{+}$at $\mathrm{pH} 9.5$ and $25^{\circ} \mathrm{C}$. The reaction was spectrophotometrically monitored at $340 \mathrm{~nm}$.

\section{Analytical methods and product characterization}

The time-course of the cascade reaction and the conversions were determined by HPLC using an Alltech OA 1000 organic acid column $(0.65 \times 30 \mathrm{~cm}) .20 \mu \mathrm{l}$ of the reaction mixture was diluted 10-fold before injection on the HPLC. Isocratic runs were performed using $4.5 \mathrm{mM} \mathrm{H}_{2} \mathrm{SO}_{4}$, with a flow rate of $0.4 \mathrm{ml}$ $\min ^{-1}$. The effluent was monitored at 210, 215, 254, and $275 \mathrm{~nm}$ and by refractive index detector.

${ }^{1} \mathrm{H}$ NMR and ${ }^{13} \mathrm{C}$ NMR spectra were recorded at 300 (75) or 400 (100) MHz. Optical rotations were determined with a Perkin Elmer 241 polarimeter. IR spectra were recorded on a Thermo Mattson IR300 equipped with a Harrick split pea ATR unit. Fast Atom Bombardment (FAB) mass spectrometry was carried out using a JEOL JMS SX/SX 102A four-sector mass spectrometer coupled to a JEOL MS-MP9021D/UPD system program.

\section{General procedure for the preparative scale one-pot four-enzyme} cascade

To a solution of $500 \mathrm{mM}$ glycerol, $250 \mathrm{mM} \operatorname{PP}_{\mathrm{i}} \quad(3: 2$ $\left.\mathrm{Na}_{2} \mathrm{PP}_{\mathrm{i}} / \mathrm{Na}_{4} \mathrm{PP}_{\mathrm{i}}\right){ }^{25} 20 \mathrm{mM}$ sodium acetate $(\mathrm{pH} 6)$, and $100 \mathrm{mM}$ aldehyde in water $10 \mathrm{U} \mathrm{mL}^{-1}$ catalase from bovine liver, $6 \mathrm{U}$ $\mathrm{mL}^{-1} \mathrm{RAMA}$, and $50 \mathrm{U} \mathrm{mL}^{-1} \mathrm{GPO}$ were added. The reactions were started by adding $3 \mathrm{U} \mathrm{mL}^{-1}$ PhoN-Sf and incubated at $20{ }^{\circ} \mathrm{C}$ under mild shaking until completion. Dephosphorylation to the end product was completed after $24 \mathrm{~h}$ and $4 \mathrm{~g}$ of silica gel was added. The reaction slurry was concentrated under reduced pressure, and the silica gel was poured on top of a silica gel column and eluted with EtOAc/MeOH (19:1). The pure fractions were collected and concentrated under reduced pressure to give the product as a light-yellow oil.

\section{Two step synthesis of D-fagomine (8)}

3-Alloc-aminopropanal (157 mg, $1.0 \mathrm{mmol}$ ) was dissolved in $\mathrm{H}_{2} \mathrm{O}$ (5.47 mL). Subsequently, glycerol (2.00 mL, $2.5 \mathrm{M} 5.0$ mmol) and $\mathrm{PP}_{\mathrm{i}}(591 \mathrm{mg}, 2.5 \mathrm{mmol})$ were added, followed by the addition of $1.00 \mathrm{~mL}$ GPO $\left(50 \mathrm{U} \mathrm{mL}^{-1}\right), 20 \mu \mathrm{L}\left(10 \mathrm{U} \mathrm{mL}^{-1}\right)$ catalase from bovine liver and $161 \mu \mathrm{L}\left(6 \mathrm{U} \mathrm{mL}^{-1}\right)$ RAMA. The reactions were initiated by adding $600 \mu \mathrm{L}\left(3 \mathrm{U} \mathrm{mL}^{-1}\right)$ PhoN-Sf and incubated until completion at $20{ }^{\circ} \mathrm{C}$ under mild shaking. Silica gel $(2 \mathrm{~g})$ was added to the reaction and the resulting mixture was concentrated under reduced pressure. The product was purified by flash chromatography (EtOAc/MeOH/19:1), giving product $7 \mathbf{b}$ in $69 \%$ yield.
$(3 S, 4 R)$ - 6 - [(Allyloxycarbonyl)amino] - 5,6 - dideoxy -2hexulose (7b, $20 \mathrm{mg}, 0.081 \mathrm{mmol})$ was dissolved in EtOH (10 $\mathrm{mL})$ and trietylsilane $(0.16 \mathrm{~mL}, 0.97 \mathrm{mmol})$ was added, followed by the addition of $\mathrm{Pd}$ on $\mathrm{C}(10 \mathrm{mg}, 0.094 \mathrm{mmol})$. The reaction mixture was stirred overnight at room temperature and filtered over Celite. The filtrate was concentrated in vacuo and purified with solid phase extraction, giving rise to D-fagomine $(\mathbf{8}, 12 \mathrm{mg}$, $0.082 \mathrm{mmol}, 100 \% .{ }^{1} \mathrm{H}$ NMR $\left(\mathrm{CD}_{3} \mathrm{OD}, 400 \mathrm{MHz}\right) \delta 3.87(\mathrm{dd}$, $J=10.9,3.1 \mathrm{~Hz}, 1 \mathrm{H}), 3.63-3.55(\mathrm{~m}, 1 \mathrm{H}), 3.42-3.38(\mathrm{~m}, 1 \mathrm{H})$, $3.11(\mathrm{t}, J=9.0 \mathrm{~Hz}, 1 \mathrm{H}), 3.02(\mathrm{ddd}, J=12.7,4.6,2.4 \mathrm{~Hz}, 1 \mathrm{H})$, 2.66-2.58 (m, 2H), 2.48-2.41 (m, 1H), 1.97-1.90 (m, 1H), 1.54 $1.43(\mathrm{~m}, 1 \mathrm{H}) ;{ }^{13} \mathrm{C} \mathrm{NMR}\left(\mathrm{CD}_{3} \mathrm{OD}, 75 \mathrm{MHz}\right) \delta 73.3,73.1,61.4$, $61.2,42.6,32.8 ;[\alpha]_{\mathrm{D}}^{20}=+6.6(c=0.60, \mathrm{MeOH})$; LRMS 148.10 $[\mathrm{M}+\mathrm{H}]^{+}$. These data are in agreement with literature. ${ }^{19}$

\section{Spectroscopic data}

5,6-Dideoxy-D-threo-2-hexulose (1a). ${ }^{1} \mathrm{H}$ NMR $\left(\mathrm{CD}_{3} \mathrm{OD}\right.$, $300 \mathrm{MHz}) \delta 4.53(\mathrm{~d}, 1 \mathrm{H}, J=19.2 \mathrm{~Hz}), 4.42(\mathrm{~d}, 1 \mathrm{H}, J=19.2$ $\mathrm{Hz}), 4.14(\mathrm{~d}, 1 \mathrm{H}, J=2.4 \mathrm{~Hz}), 3.78(\mathrm{dt}, 1 \mathrm{H}, J=2.4,6.0 \mathrm{~Hz})$, $1.65-1.50(\mathrm{~m}, 2 \mathrm{H}), 0.96(\mathrm{t}, 3 \mathrm{H}, J=7.4 \mathrm{~Hz}) ;{ }^{13} \mathrm{C} \mathrm{NMR}\left(\mathrm{CD}_{3} \mathrm{OD}\right.$, $75 \mathrm{MHz}) \delta 212.0,77.1,73.2,66.0,25.3,8.7 ;[\alpha]_{\mathrm{D}}^{20}-17.7(c 0.22$, $\mathrm{MeOH}$ ); IR (neat) 1723, $3397 \mathrm{~cm}^{-1}$; LRMS $149.08[\mathrm{M}+\mathrm{H}]^{+}$, $171.09[\mathrm{M}+\mathrm{Na}]^{+}$. These data are in agreement with literature. ${ }^{10}$

5,6,7-Trideoxy-D-threo-2-heptulose (1b). ${ }^{1} \mathrm{H}$-NMR $\left(\mathrm{CD}_{3} \mathrm{OD}, 300 \mathrm{MHz}\right) \delta 4.47(\mathrm{q}, 2 \mathrm{H}, J=19.2 \mathrm{~Hz}), 4.11(\mathrm{~d}$, $1 \mathrm{H}, J=2.3 \mathrm{~Hz}), 3.89(\mathrm{dt}, 1 \mathrm{H}, J=2.4,6.7 \mathrm{~Hz}), 3.30(\mathrm{td}, 1 \mathrm{H}$, $J=1.6,3.1 \mathrm{~Hz}), 1.56-1.40(\mathrm{~m}, 4 \mathrm{H}), 0.95(\mathrm{t}, 3 \mathrm{H}, J=7.2 \mathrm{~Hz})$; ${ }^{13} \mathrm{C}-\mathrm{NMR}\left(\mathrm{CD}_{3} \mathrm{OD}, 75 \mathrm{MHz}\right) \delta 211.9,77.5,71.4,66.0,34.5$, $\left.18.2,12.4 ;[\alpha]_{\mathrm{D}}^{20}-14.1(c 0.29, \mathrm{MeOH})\right)$; IR (neat) 1722, 3367 $\mathrm{cm}^{-1}$; LRMS $163.10[\mathrm{M}+\mathrm{H}]^{+}, 185.12[\mathrm{M}+\mathrm{Na}]^{+}$.

5,6-Dideoxy-5-methyl-D-threo-2-hexulose (1c). ${ }^{1} \mathrm{H} \quad \mathrm{NMR}$ $\left(\mathrm{CD}_{3} \mathrm{OD}, 300 \mathrm{MHz}\right) \delta 4.53(\mathrm{~d}, 1 \mathrm{H}, J=19.2 \mathrm{~Hz}), 4.44(\mathrm{~d}, 1 \mathrm{H}, J=$ $19.2 \mathrm{~Hz}), 4.31(\mathrm{~d}, 1 \mathrm{H}, J=1.8 \mathrm{~Hz}), 3.45(\mathrm{dd}, 1 \mathrm{H}, J=2.0,9.1 \mathrm{~Hz})$, $1.90(\mathrm{ddd}, 1 \mathrm{H}, J=2.3,6.7,13.4 \mathrm{~Hz}), 1.01(\mathrm{~d}, 3 \mathrm{H}, J=6.7 \mathrm{~Hz}), 0.93$ $(\mathrm{d}, 3 \mathrm{H}, J=6.7 \mathrm{~Hz}) ;{ }^{13} \mathrm{C}$ NMR $\left(\mathrm{CD}_{3} \mathrm{OD}, 75 \mathrm{MHz}\right) \delta 212.6,77.4$, $75.8,65.9,29.8,17.8,17.6 ;[\alpha]_{\mathrm{D}}^{20}-12.2(c 0.16, \mathrm{MeOH})$; IR (neat) $1723,3396 \mathrm{~cm}^{-1}$; LRMS $163.10[\mathrm{M}+\mathrm{H}]^{+}, 185.12[\mathrm{M}+\mathrm{Na}]^{+}$.

(3S,4R)-6-[(Benzyloxycarbonyl)amino]-5,6-dideoxy-2-hexulose (7a). ${ }^{1} \mathrm{H}-\mathrm{NMR}\left(\mathrm{CD}_{3} \mathrm{OD}, 400 \mathrm{MHz}\right) \delta 7.48-7.21(\mathrm{~m}, 5 \mathrm{H})$, 5.19-5.02 (2H, m), 4.48 (q, 2H, $J=16.4 \mathrm{~Hz}), 4.19-4.09(\mathrm{~m}, 1 \mathrm{H})$, $3.97(\mathrm{t}, 1 \mathrm{H}, J=7.2 \mathrm{~Hz}), 3.29-3.19(\mathrm{~m}, 2 \mathrm{H}), 1.76(\mathrm{q}, 2 \mathrm{H}, J=$ $8.8 \mathrm{~Hz}) ;{ }^{13} \mathrm{C}\left(\mathrm{CD}_{3} \mathrm{OD}, 75 \mathrm{MHz}\right) \delta 213.5,159.2,138.6,129.6$, $129.1,129.0,79.6,71.3,68.0,67.6,38.9,34.6$. These data are in agreement with literature. ${ }^{19}$

(3S,4R)-6-[(Allyloxycarbonyl)amino]-5,6-dideoxy-2-hexulose (7b). ${ }^{1} \mathrm{H}-\mathrm{NMR}\left(\mathrm{CD}_{3} \mathrm{OD}, 400 \mathrm{MHz}\right) \delta 7.13-6.60(1 \mathrm{H}, \mathrm{m})$, $6.12-5.67(1 \mathrm{H}, \mathrm{m}), 5.25(\mathrm{~d}, 1 \mathrm{H}, J=18 \mathrm{~Hz}), 5.17(\mathrm{~d}, 1 \mathrm{H}, J=9.0$ $\mathrm{Hz}), 4.65-4.30(\mathrm{~m}, 4 \mathrm{H}), 4.10(\mathrm{~d}, 1 \mathrm{H}, J=3.0 \mathrm{~Hz}), 3.96(\mathrm{dt}, 1 \mathrm{H}$, $J=7.5,3.0 \mathrm{~Hz}), 3.55(\mathrm{~s}, 2 \mathrm{H}), 3.20(\mathrm{~s}, 1 \mathrm{H}), 1.74(\mathrm{q}, 2 \mathrm{H}, J=6$ $\mathrm{Hz}) ;{ }^{13} \mathrm{C}\left(\mathrm{CD}_{3} \mathrm{OD}, 75 \mathrm{MHz}\right) \delta 213.7,134.8,117.7,79.7,71.4$, 68., 66.6, 38.9, 34.7; IR (neat) 1649, 1689, $3338 \mathrm{~cm}^{-1}$; LRMS $248.10[\mathrm{M}+\mathrm{H}]^{+}, 270.3[\mathrm{M}+\mathrm{Na}]^{+}$. 


\section{Acknowledgements}

This research was performed under the ACTS-NWO Integration of Biosynthesis \& Organic Synthesis (IBOS) program. The companies MSD (Oss, NL), DSM (Geleen, NL) and Syncom (Groningen, NL) are kindly acknowledged for financial support. We also wish to thank Dr M. Schürmann (DSM, Geleen) for providing the plasmids harboring the aldolase genes.

\section{Notes and references}

1 (a) A. Bruggink, R. Schoevaart and T. Kieboom, Org. Process Res. Dev., 2003, 7, 622-640; (b) R. A Sheldon, in Multi-step enzyme catalysis: Biotransformations and chemoenzymatic synthesis, ed. E. García-Junceda, Wiley-VCH, Weinheim, 2008, Ch. 6, pp. 109-136.

2 R. A. Sheldon, Chem. Commun., 2008, 3352-3365.

3 S. M. Dean, W. A. Greenberg and C.-H. Wong, Adv. Synth. Catal., 2007, 349, 1308-1320.

4 (a) Y. Ichikawa, Y. Igarashi, M. Ichikawa and Y. Suhara, J. Am. Chem. Soc., 1998, 120, 3007-3018; (b) Iminosugars: from synthesis to therapeutic applications, ed. P. Compain and O. R. Martin, WileyVCH, Weinheim, 2007; (c) N. Asano, Cell. Mol. Life Sci., 2009, 66, 1479-1492.

5 (a) M. Movassaghi and E. N. Jacobsen, Science, 2002, 298, 1904 1905; (b) S. Y. Ko, A. W. M. Lee, S. Masamune, L. A. Reed, K. B. Sharpless and F. J. Walker, Science, 1983, 220, 949-951.

6 A. B. Northrup and D. W. C. MacMillan, Science, 2004, 305, 17521755.

7 (a) H. J. M. Gijsen and C.-H. Wong, J. Am. Chem. Soc., 1995, 117, 7585-7591; (b) K. M. Koeller and C.-H. Wong, Chem. Rev., 2000, 100, 4465-4494; (c) P. Clapés, W.-D. Fessner, G. A. Sprenger and A. K. Samland, Curr. Opin. Chem. Biol., 2010, 14, 154-167.

8 (a) A. Bolt, A. Berry and A. Nelson, Arch. Biochem. Biophys., 2008, 474, 318-330; (b) M. G. Silvestri, G. Desantis, M. Mitchell and C.-H. Wong, Top. Stereochem., 2003, 23, 267-342; (c) M. Schumperli, R. Pellaux and S. Panke, Appl. Microbiol. Biotechnol., 2007, 75, 33-45.
9 D. C. Crans and G. M. Whitesides, J. Am. Chem. Soc., 1985, 107, 7019-7026.

10 W.-D. Fessner and G. Sinerius, Angew. Chem., Int. Ed. Engl., 1994, 33, 209-212.

11 O. Eyrisch, G. Sinerius and W.-D Fessner, Carbohydr. Res., 1993, 238, 287-306.

12 C. H. Wong and G. M Whitesides, J. Org. Chem., 1983, 48, 31993205.

13 R. Schoevaart, F. van Rantwijk and R. A. Sheldon, J. Org. Chem., 2000, 65, 6940-6943.

14 T. van Herk, A. F. Hartog, H. E. Schoemaker and R. Wever, J. Org. Chem., 2006, 71, 6244-6247.

15 T. van Herk, A. F. Hartog, A. M. van der Burg and R. Wever, $A d v$. Synth. Catal., 2005, 347, 1155-1162.

16 M. D. Bednarski, E. S. Simon, N. Bischofberger, W.-D. Fessner, M. J. Kim, W. Lees, T. Saito, H. Waldmann and G. M. Whitesides, J. Am. Chem. Soc., 1989, 111, 627-635.

17 K. Faber, Biotransformations in Organic Chemistry, 5th ed., SpringerVerlag, Berlin, 2004, pp. 277-284.

18 A. Kato, N. Asano, H. Kizu and K. Matsui, J. Nat. Prod., 1997, 60, $312-314$.

19 (a) N. Kumari, B. G. Reddy and Y. D. Vankar, Eur. J. Org. Chem., 2009, 160-169; (b) L. Bartali, D. Scarpi, A. Guarna, C. Prandi and E. G. Occhiato, Synlett, 2009, 913-916.

20 M. Sugiyama, Z. Hong, P.-H. Liang, S. M. Dean, L. J. Whalen, W. A. Greenberg and C.-H. Wong, J. Am. Chem. Soc., 2007, 129, 14811-14817, and references cited therein.

21 P. K. Mandl and J. S. McMurray, J. Org. Chem., 2007, 72, 6599-6601.

22 J. A. Castillo, J. Calveras, J. Casas, M. Mitjans, M. Pilar Vinardell, T. Parella, T. Inoue, G. A. Sprenger, J. Joglar and P. Clapés, Org. Lett., 2006, 8, 6067-6070.

23 N. Tanaka, Z. Hasan, A. F. Hartog, T. van Herk and R. Wever, Org. Biomol. Chem., 2003, 1, 2833-2839.

24 H. U. Bergmeyer, K. Gawehn, M. Grassl, Glucose-6-phosphate dehydrogenase from yeast, in Methods of Enzymatic Analysis, ed. $\mathrm{H}$. U. Bergmeijer, Verlag Chemie, vol. 1, 1986, pp. 458-459.

$25 \mathrm{PP}_{\mathrm{i}}$ was added as a mixture of 3.5 equiv. $(350 \mathrm{mg}) \mathrm{Na}_{2} \mathrm{PP}_{\mathrm{i}}$ and 2 equiv. (241 mg) $\mathrm{Na}_{4} \mathrm{PP}_{\mathrm{i}}$ resulting in a buffered solution of $\mathrm{pH} 6$. 